Permission for the work has been given by Lord Barnard, the owner, and the work will be under the direction of Miss Kenyon. Excavation will begin in the current year, and it is hoped will be completed in 1940. A committee has been appointed for the purpose of raising funds to meet the cost of excavation, of which Mr. A. W. Clapham, president of the Society of Antiquaries, is chairman, with Sir Charles Marston and Sir Frederic Kenyon as vice-chairmen, while among the members of the committee are Isord Harlech, Lord Powis, Lord Baldwin, Sir Charles Peers, Dr. R. E. Mortimer Wheeler and Mr. J. P. Bushe-Fox. Contributions to the excavation fund may be sent to the Assistant Secretary, Society of Antiquaries, Burlington House, Piccadilly, London, W.1.

\section{Imperial Studies in Chinese Archæology}

OwING to the preoccupation of Chinese antiquarians with literary rather than material evidence, an exceptional interest attaches to an imperial scroll now on exhibition in London, which was painted in A.D. 1729 by command of the Emperor Yung Chen. The scroll is of paper, measuring 49 feet long by $24 \frac{1}{2}$ inches wide, and forms an illustrated record in colour of some of the personal possessions of the Emperor, including objects in bronze, jade, ivory, pottery and porcelain. More than two hundred objects are represented. To the student of Chinese archæology and the development of Chinese art, the interest of this early catalogue lies in the fact that the objects range in date from the early Chou dynasty, about the close of the second millennium B.c., down to porcelains of the early eighteenth century of our era. It is, in fact, a contemporary manuscript catalogue, illustrated by hand, of a remarkable collection of antiquities, which are shown as a continuous band of colour plates. At the time the scroll was painted, the Emperor, who died in 1735, was engaged in preparing the plans for his tomb; and it was from this tomb that the scroll was obtained by a British officer at the time of the Boxer Rebellion. It is now on view at the galleries of Messrs. Spink and Son, 5-7 King Street, St. James's, in aid of the Maternity Ward of the Royal Northern Hospital, London. As no scroll of this type has previously been exhibited in Europe, it has been displayed at full length on the walls of the exhibition hall and is accompanied by a key, in which the various objects have been drawn in outline with notes by experts on their type and ceremonial use. In view of the wide range in character and date of the objects depicted, the value of the scroll thus elucidated for archæological and æsthetic studies is obviously considerable.

\section{The History of Cement}

THE summer meeting of the Newcomen Society was held in Suffolk on June 7-10 with Ipswich as the headquarters. The itinerary included visits to the bell cage at East Bergholt, weaving factories at Sudbury and Hadleigh, the post mill at Saxstead, the tide mill and steelyard at Woodbridge and the works of Ransome's, Sims and Jefferies, Ltd. After the annual dinner on June 8 three papers were read, one of them being by Dr. A. P. Thurston on 'Parker's 'Roman' Cement". In 1796, James Parker, of whom little is known, took out a patent for "Cement or Terras to be used in Aquatic and other Buildings and Stucco Work". This cement was made by burning in kilns the hard stone-like concretions called septaria, found around the coasts of Essex and Kent wherever the London clay bordered the shore and formed low cliffs. Previously this material had been used for building, but when the making of Parker's cement began there was a great demand for it, and the practice grew up of dredging it from the bottom of the sea off Walton-on-Naze and elsewhere. In 1857 there were between three and four hundred smacks engaged in this dredging. The principal factories for cement manufacture were at Harwich, and at one of these 'Roman' cement was made until 1890. Joseph Aspdin's patent for 'Portland' cement was taken out in 1824 , but it was the improvements effected in its manufacture by I. C. Johnson at Swanscombe which led to 'Portland' cement superseding 'Roman' cement. Dr. Thurston's paper was accompanied by a bibliography of the subject.

\section{New B.B.C. Stations}

ON June 14, the revised West Regional Scheme of the British Broadcasting Corporation was brought into operation by the opening of the new transmitting stations at Start Point and Clevedon. These stations now radiate simultaneously the West Regional programme on wave-lengths of 285.7 and 203.5 metres respectively. The Start Point station is situated near the most southerly point of Devon, and is intended to serve the whole of the south coast from Cornwall to Hampshire or Sussex ; while Clevedon on the North Somerset coast will serve the areas around Bristol, and the northerly parts of Somerset and Devon which cannot be covered satisfactorily from Start Point. Both stations have been so located as to take advantage of transmission largely over a sea path, and thus avoid the heavy attenuation of signal strength encountered in wave propagation over the poorly conducting terrain of Dartmoor.

Some technical details of the Start Point station were given in the Wireless World of June 15, from which it is learned that the new station is at present using a power of $100 \mathrm{kw}$, which will ultimately be raised to $150 \mathrm{kw}$. In order to give the greatest service along the south coast, the aerial system has been designed to give its maximum radiation in the east and west direction, with a minimum, but by no means negligible, radiation in a southerly direction over the English Channel. This directional radiation has been secured by the use of two steel mastradiators, $450 \mathrm{ft}$. high, spaced about three eighths of a wave-length apart. Both mast aerials are connected to the transmitter, one directly and the other through a suitable phase-shifting network. This network has been carefully adjusted during the initial test-period to give the desired distribution of signal radiation 